\title{
Effect of compounds with antibacterial activities in human milk on respiratory syncytial virus and cytomegalovirus in vitro
}

\author{
J. PORTELLI, A. GORDON and J. T. MAY \\ School of Microbiology, LaTrobe University, Bundoora, Victoria 3083, Australia
}

\begin{abstract}
The effect of some antibacterial compounds present in human milk were tested for antiviral activity against respiratory syncytial virus, Semliki Forest virus and cytomegalovirus. These included the gangliosides GM1, GM2 and GM3, sialyl-lactose, lactoferrin and chondroitin sulphate $A, B$ and $C$, which were all tested for their ability to inhibit the viruses in cell culture. Of the compounds tested, only the ganglioside GM2, chondroitin sulphate $B$ and lactoferrin inhibited the absorption and growth of respiratory syncytial virus in cell culture, and none inhibited the growth of Semliki Forest virus, indicating that lipid antiviral activity was not associated with any of the gangliosides. While the concentrations of these two compounds required to inhibit respiratory syncytial virus were in excess of those present in human milk, sialyl-lactose concentrations similar to those present in human milk increased the growth of cytomegalovirus. Lactoferrin was confirmed as inhibiting both respiratory syncytial virus and cytomegalovirus growth in culture even when used at lower concentrations than those present in human milk. The antiviral activities of GM2, chondroitin sulphate $B$ and lactoferrin were tested when added to an infant formula. Lactoferrin continued to have antiviral activity against cytomegalovirus, but a lower activity against respiratory syncytial virus; ganglioside GM2 and chondroitin sulphate B still maintained antiviral activity against respiratory syncytial virus.
\end{abstract}

\section{Introduction}

Breast-feeding protects against both respiratory and gastrointestinal infections in infants. Human milk contains not only specific secretory IgA to viruses, but also various other factors that can inhibit viruses, including the infant pathogenic virus, respiratory syncytial virus (RSV) $[1,2]$. These inhibitors of RSV, some of which still remain to be identified, can be of small [2] or large, $(>400000)$ mol.wt [1]. Some components of milk with known in-vitro antiviral or antibacterial activity (or as recently found, with both activities) [3-5], are present only in human milk, or in higher concentrations in human milk than in either bovine milk or formula preparations. Many other milk components have yet to be tested for antiviral activity against many viruses including RSV [6]. RSV remains the major cause of serious lower respiratory tract disease in infants [6]. Another virus that infects infants, cytomegalovirus (CMV), is commonly found in CMV

Received 30 Sept. 1997; revised version accepted 11 March 1998.

Corresponding author: Dr J. T. May. seropositive mothers' milk with about two-thirds of the infants who receive virus-containing milk becoming infected, without developing any symptomatic disease [6].

Gangliosides are found in both human and bovine milk and are a component of the milk fat globule membrane [7, 8]. They are glycolipids composed of a small oligosaccharide chain consisting of at least one sialic acid sugar, linked to a lipid ceramide [9]. The level of total gangliosides in both human and bovine milk is $c .11 \mu \mathrm{g} / \mathrm{ml}$, but formula feeds contain about half this concentration [7]; processing of bovine milk for infant formula removes the fat globule membrane [10]. The composition of individual gangliosides is also different in the milks. In human milk, GM3 (monosialo-; $74 \%$ of total gangliosices) is at a higher concentration than GM2 (monosialo-; 2\%) and GM1 (monosialo-; 0.1\%), while in bovine milk GM3 constitutes only a minor component (3\%); all have a single sialyl-lactose structure associated with them $[7,11]$. The major ganglioside found in bovine milk is GD3 (disialo-; 80\% ). GM3 linked with an additional $\mathrm{N}$-acetyl-galactosamine $\left(1^{\prime}-4^{\prime}\right)$ becomes GM2 and 
GM2 linked further with galactose $\left(1^{\prime}-3^{\prime}\right)$ constitutes GM1 [11]. While GM1 and GM3 can stop the binding of Escherichia coli to intestinal cells [11] and GM1 is a known receptor for the cholera and $E$. coli toxins $[10,11]$, the possible role of gangliosides as antiviral receptors in human milk has not been investigated. Gangliosides GM2 and GM3 can bind group A porcine rotavirus [12], with GM1 thought to bind simian rotavirus SA-11 $[12,13]$. Human rotaviruses bind to GM1 devoid of the sialic acid structure (asialo-GM1) [14], a ganglioside structure not found in milk. However, whether actual binding of rotaviruses by gangliosides in human milk can occur during breast-feeding is unknown.

In addition to gangliosides, the fat globule membrane of human milk also contains glycosaminoglycans (150$250 \mu \mathrm{g} / \mathrm{mg}$ of membrane) at a concentration 10 -fold higher than that found in bovine milk [10]. Components of glycosaminoglycan include the large linear heteropolysaccharides (c. $30000 \mathrm{~mol} . \mathrm{wt}$ ), chondroitin sulphate $\mathrm{A}$ and $\mathrm{C}$ which inhibit binding of the human immunodeficiency virus (HIV) glycoprotein gp120 to its host cell $\mathrm{CD} 4$ receptor, whereas chondroitin sulphate B (dermatan sulphate) has no effect on HIV binding [10].

Human milk also contains 100 -fold more free sialyllactose $(0.9 \mathrm{mg} / \mathrm{ml})$ compared with bovine milk $(60 \mu \mathrm{g} / \mathrm{ml})$ [15]. Sialyl-lactose is part of the chemical structure of sialo-containing gangliosides such as GM1, GM2 and GM3. The unbound sugar sialyllactose is known to inhibit the effect of cholera toxin [9], binds Helicobacter pylori and may bind influenza virus [15].

The antibacterial glycoprotein lactoferrin, which has bacteriostatic or bactericidal activities against various of bacteria and anti-adhesion properties against enterotoxogenic $E$. coli, is present in mature human milk at $1 \mathrm{mg} / \mathrm{ml}$ and much lower levels in bovine milk $(0.1 \mathrm{mg} / \mathrm{ml})$ and in infant formula [3]. Lactoferrin has recently been found to have antiviral properties and to inhibit the growth of HIV [4], CMV [4, 5], herpes simplex virus [5] and RSV [3]. This antiviral activity stopped host cell absorption or penetration by these viruses and for CMV resides in the protein moiety of the glycoprotein [4].

\section{Materials and methods}

Purified commercially available lactoferrin and sialyllactose (both from human milk), gangliosides GM1, GM2, GM3 and chondroitin sulphate A (4-sulphate), C (6-sulphate) and B (dermatan sulphate) were purchased from Sigma. The gangliosides were dissolved at a concentration of $1 \mathrm{mg} / \mathrm{ml}$ and the others at $5 \mathrm{mg} / \mathrm{ml}$ in phosphate-buffered saline (PBS) and used fresh or stored at $-20^{\circ} \mathrm{C}$ for a week. Semliki Forest virus (SFV) titre was determined by a plaque technique on established cell lines by an agarose $1 \%$ overlay method as described previously [16] and in RSV plaquing the agarose overlay was replaced with methyl cellulose $1 \%$ [3]. SFV was grown on baby hamster kidney (BHK-21) cells for 3 days and RSV (Long strain) on human epidermoid carcinoma (HEp-2) cells for 4 days, all at $36^{\circ} \mathrm{C}$ [3]. CMV (clinical isolate) plaques were counted after 7 days on near confluent human embryo lung (HEL) cells grown in $25-\mathrm{cm}^{2}$ tissue culture flasks, without use of a solid overlay [5]. The effects of various concentrations of gangliosides $(50-500 \mu \mathrm{g} / \mathrm{ml})$, sialyl-lactose $(50-2500 \mu \mathrm{g} / \mathrm{ml})$ and chondroitin sulphates $(50-2500 \mu \mathrm{g} / \mathrm{ml})$ were tested for their inhibitory action on $80-100$ plaque-forming units (in $0.1 \mathrm{ml}$ ) of virus in duplicate, and in at least triplicate experiments, with selected concentrations as presented in Table 1. Results are not shown in Table 1 when the compound concentrations damaged any of the three different types of cell monolayers, as each of the cells had different sensitivity to the compounds. The compounds $(0.1 \mathrm{ml}$ of the concentrations indicated in Table 1) were absorbed on to cells $30 \mathrm{~min}$ before the absorption of the viruses, which was $1 \mathrm{~h}$ before the overlay medium was added, unless indicated otherwise. The compounds were present during the absorption of the virus, and the concentrations used did not damage the cell monolayers. The compounds were added to freshly prepared infant formula (S-26 powder, Wyeth), prepared as described by the manufacturer, for testing. The compound-supplemented infant formula was removed from the cells after virus absorption.

\section{Results and discussion}

With this in-vitro antiviral test system it is apparent from the effect of the gangliosides on virus plaque numbers that GM2 can have an inhibitory effect (up to $90 \%$ reduction at $500 \mu \mathrm{g} / \mathrm{ml}$ ) on $\mathrm{RSV}$ and no activity against SFV or CMV (Table 1). No lipid antiviral activity was associated with the gangliosides, as pretreatment of SFV [16] for $1 \mathrm{~h}$ at $37^{\circ} \mathrm{C}$ with a final concentration of the gangliosides of $50-500 \mu \mathrm{g} / \mathrm{ml}$ had no effect on the virus titre. SFV is used to detect nonspecific lipid antiviral activity against enveloped viruses [16]. Lipids such as those of the ceramide moiety of gangliosides which contain two fatty acid chains have very low lipid antiviral activity [16, 17]. However, when RSV was pretreated with the gangliosides at $200 \mu \mathrm{g} / \mathrm{ml}$ for $1 \mathrm{~h}$ at $37^{\circ} \mathrm{C}$, rather than the gangliosides being absorbed to the cells for $30 \mathrm{~min}$ before the virus absorption, GM3 had no effect on the RSV titre, whereas GM2 inhibited the titre by $85 \%$ and GM1 by $45 \%$. These inhibitory values are similar to those for GM2 and GM1 (and negligible inhibition by GM3) shown in Table 1 for cells pretreated with the gangliosides for $30 \mathrm{~min}$ before the addition of RSV. These results would suggest that the ganglioside GM2 binds to RSV and inhibits the virus absorption to HEp- 
Table 1. Inhibition of virus growth by various compounds found in human milk

\begin{tabular}{|c|c|c|c|c|c|c|c|c|c|c|c|c|c|c|}
\hline \multirow[b]{3}{*}{ Compound } & \multicolumn{14}{|c|}{ Percentage inhibition of virus growth ${ }^{*}$ by compound concentrations $(\mu \mathrm{g} / \mathrm{ml})$} \\
\hline & \multicolumn{6}{|c|}{ RSV } & \multicolumn{3}{|c|}{ SFV } & \multicolumn{5}{|c|}{ CMV } \\
\hline & 50 & 100 & 200 & 500 & 1000 & 2500 & 500 & 1000 & 2500 & 100 & 200 & 500 & 1000 & 2500 \\
\hline \multicolumn{15}{|l|}{ Gangliosides } \\
\hline GM1 & 0 & 15 & 40 & 50 & & & 0 & & & & & & 0 & 0 \\
\hline $\mathrm{GM} 2$ & 15 & 45 & 70 & 90 & & & 0 & & & & & & 0 & 0 \\
\hline GMF3 & 0 & 0 & 10 & 30 & & & 0 & & & & & & 0 & 0 \\
\hline Sialyl-lactose & 0 & 0 & 0 & 0 & 0 & 0 & 0 & 0 & 0 & $+20^{\dagger}$ & $+20^{\dagger}$ & $+80^{\dagger}$ & & \\
\hline \multicolumn{15}{|c|}{ Chondroitin sulphate } \\
\hline A & 0 & 0 & 0 & 0 & 0 & 0 & 0 & 0 & 10 & & & 0 & 10 & 10 \\
\hline $\mathrm{B}$ & 0 & 0 & 0 & 0 & 30 & 80 & 0 & 0 & 15 & & & 15 & 20 & 20 \\
\hline $\mathrm{C}$ & 0 & 0 & 0 & 0 & 0 & 30 & 0 & 0 & 0 & & & 0 & 5 & 5 \\
\hline
\end{tabular}

* Inhibition of virus plaques.

Percentage activation of virus titre.

2 cells rather than inactivating the virus by destruction of the RSV lipid envelope.

When chondroitin sulphates $\mathrm{A}, \mathrm{B}$ and $\mathrm{C}$ were tested for antiviral activity by addition to cells before virus absorption, significant inhibitory activity against RSV was associated with chondroitin sulphate $B$ at $2.5 \mathrm{mg} / \mathrm{ml}$ (Table 1). When RSV was pretreated with the chondroitin sulphates at $2.5 \mathrm{mg} / \mathrm{ml}$ at $37^{\circ} \mathrm{C}$ for $1 \mathrm{~h}$, again only chondroitin sulphate $\mathrm{B}$ had a significant inhibitory activity (85\%) and was similar to that shown in Table 1; chondroitin sulphate $\mathrm{C}$ again had a low inhibitory effect $(30 \%)$ and chondroitin sulphate A possessed no inhibitory activity. Similar pretreatments with the chondroitin sulphates at $1 \mathrm{mg} / \mathrm{ml}$ found that only chondroitin sulphate B inhibited RSV $(40 \%)$. This would suggest that, like GM2, chondroitin sulphate B may also bind to the virus and inhibit its absorption. These chondroitin sulphates have no associated lipid structure. Neither chondroitin sulphate B nor GM2 had any inhibitory effect on SFV when it was plaqued on HEp-2 cells, indicating that the effects were specific for RSV. No significant activity of the chondroitin sulphates was found against CMV.

The sugar sialyl-lactose from human milk had no antiviral activity against RSV or CMV even at
$2.5 \mathrm{mg} / \mathrm{ml}$ (Table 1), but CMV was found to be consistently activated by sialyl-lactose. Lactoferrin $(0.1-1 \mathrm{mg} / \mathrm{ml})$ also inhibited both RSV (80-85\%) [see also 3] and CMV (90-95\%) [see also 4, 5]. The sialyl-lactose activation of CMV (Table 1) was negated if lactoferrin was also added, with lactoferrin inhibiting CMV growth by $95 \%$.

The compounds that were found to have antiviral activity against RSV or CMV (ganglioside GM2, chondroitin sulphate $\mathrm{B}$ and lactoferrin) or to activate CMV infectivity (sialyl-lactose) were tested for their ability to maintain their activity when added to an infant formula that contained low levels of these compounds. The antiviral activity of lactoferrin decreased significantly against RSV (85\% to $30 \%$; Table 2) but not against CMV (Table 2), when added to this infant formula. Ganglioside GM2 and chondroitin sulphate B maintained their activity against RSV; the activating effect of sialyl-lactose on CMV was significantly decreased when it was added to the formula.

Of the gangliosides tested that were found to have antiviral activity against RSV, GM2 had the most significant effect at a concentration of $200 \mu \mathrm{g} / \mathrm{ml}$; GM1 had less inhibitory activity and no activity was

Table 2. Inhibition of virus growth after the addition of compounds to infant formula

\begin{tabular}{|c|c|c|}
\hline \multirow[b]{2}{*}{ Compound additions* } & \multicolumn{2}{|c|}{ Percentage inhibition ${ }^{\dagger}$} \\
\hline & Respiratory syncytial virus & Cytomegalovirus \\
\hline Nil & 0 & 0 \\
\hline Formula & 5 & $+10^{\ddagger}$ \\
\hline Formula + sialyl-lactose $0.5 \mathrm{mg} / \mathrm{ml}$ & 5 & $+25^{\ddagger}$ \\
\hline Formula + sialyl-lactose $0.5 \mathrm{mg} / \mathrm{ml}+$ lactoferrin $1 \mathrm{mg} / \mathrm{ml}$ & 30 & 95 \\
\hline Formula + lactoferrin $0.1 \mathrm{mg} / \mathrm{ml}$ & 5 & 30 \\
\hline Formula + lactoferrin $0.5 \mathrm{mg} / \mathrm{ml}$ & 30 & 95 \\
\hline Formula + lactoferrin $1 \mathrm{mg} / \mathrm{ml}$ & 30 & 98 \\
\hline Formula + GM2 $0.5 \mathrm{mg} / \mathrm{ml}$ & 75 & 0 \\
\hline Formula + chondroitin sulphate B $2.5 \mathrm{mg} / \mathrm{ml}$ & 85 & 20 \\
\hline
\end{tabular}

* Percentage inhibition values without formula are indicated in Table 1 ; lactoferrin concentrations used $(0.1-1 \mathrm{mg} / \mathrm{ml})$ inhibited $\mathrm{RSV}$ by $80 \%$ and CMV by $95 \%$ when not added to the formula.

Percentage inhibition of virus plaques.

${ }^{\ddagger}$ Percentage activation of virus titre. 
found with the major ganglioside present in mature human milk, GM3. As GM2 constitutes only $2 \%$ of the total gangliosides in human milk $(0.2 \mu \mathrm{g} / \mathrm{ml})$ [8] and because of its low concentration in milk, it would not be expected to have any antiviral activity against RSV during breast-feeding. At the high concentrations tested, GM2 maintained its antiviral activity when added to an infant formula. This is unlike that found previously for the potent antiviral lipid mono-olein [17]; when added to infant formula, this required concentrations of $15 \mathrm{mg} / \mathrm{ml}$ to significantly inhibit of RSV in cell culture [18] and there was no inhibition of SFV at $10 \mathrm{mg} / \mathrm{ml}$ [17]. Similarly, chondroitin sulphate B (dermatan sulphate) was found to have significant antiviral activity against RSV in the present study, but only at concentrations higher than the total fat globule glycosaminoglycan (of which chondroitin sulphate B is only a small component), and would not be expected to have any anti-RSV activity during breast-feeding. In contrast, lactoferrin has recently been shown to inhibit RSV [3] and CMV [4,5] at concentrations well below those present in human milk. When tested after its addition to one infant formula, its antiviral activity against RSV decreased rapidly, but not that against CMV. Lactoferrin, which is present at high concentrations in colostrum $(6 \mathrm{mg} / \mathrm{ml})$, has been suggested to account for the low isolation rate of CMV from CMV-positive mothers' colostrum on HEL cells, [4]. Sialyl-lactose had no effect on RSV at 30-fold the concentration present in milk, but actually activated CMV, even at concentrations lower than that present in human milk, an activity which was significantly reduced when added to the infant formula. The concentrations of GM2 and chondroitin sulphate B required to achieve antiviral activity against RSV in vitro are in excess of that found in human milk, making it unlikely that they constitute a major non-specific antiviral factor in human milk against this infant pathogen, but could be one of the small unidentified inhibitors of RSV previously isolated from human milk [2]. Lactoferrin was the most effective of the compounds, inhibiting RSV and CMV and maintaining its antiviral activity against CMV when added to an infant formula. Thus, some of the previously described antibacterial factors in human milk [19] also possess potent antiviral activity against viruses that infect infants.

\section{References}

1. Lægreid A, Kolstø Otnæss A-B, Ørstavik I, Carlsen KH. Neutralizing activity in human milk fractions against respiratory syncytial virus. Acta Paediatr Scand 1986; 75: 696-701.

2. Toms GL, Gardner PS, Pullan CR, Scott M, Taylor C. Secretion of respiratory syncytial virus inhibitors and antibody in human milk throughout lactation. $J$ Med Virol 1980; 5: $351-360$.

3. Grover M, Giouzeppos O, Schnagl RD, May JT. Effect of human milk prostaglandins and lactoferrin on respiratory syncytial virus and rotavirus. Acta Paediatr 1997; 86: 315-316.

4. Harmsen MC, Swart PJ, de Bèthune M-P et al. Antiviral effects of plasma and milk proteins: lactoferrin shows potent activity against both human immunodeficiency virus and human cytomegalovirus replication in vitro. J Infect Dis 1995; 172: 380-388.

5. Hasegawa K, Motsuchi W, Tanaka S, Dosako S. Inhibition with lactoferrin of in vitro infection with human herpes virus. Jpn $J$ Med Sci Biol 1994; 47: 73-85.

6. May JT. Antimicrobial factors and microbial contaminants in human milk: recent studies. J Paediatr Child Health 1994; 30; $470-475$.

7. Lægreid A, Otnæss A-BK, Fuglesang J. Human and bovine milk: comparison of ganglioside composition and enterotoxininhibitory activity. Pediatr Res 1986; 20: 416-421.

8. Rueda R, Maldonado J, Gil A. Comparison of content and distribution of human milk gangliosides from Spanish and Panamanian mothers. Ann Nutr Metab 1996; 40: 194-201.

9. Idota T, Kawakami H, Murakami Y, Sugawara M. Inhibition of cholera toxin by human milk fractions and sialyllactose. Biosci Biotechnol Biochem 1995; 59: 417-419.

10. Newburg DS, Linhardt RJ, Ampofo SA, Yolken RH. Human milk glycosaminoglycans inhibit HIV glycoprotein gp120 binding to its host cell CD4 receptor. J Nutr 1995; 125: 419-424.

11. Idota $T$, Kawakami H. Inhibitory effects of milk gangliosides on the adhesion of Escherichia coli to human intestinal carcinoma cells. Biosci Biotech Biochem 1995; 59: 69-72.

12. Rolsma MD, Gelberg HB, Kuhlenschmidt MS. Assay for evaluation of rotavirus-cell interactions: identification of an enterocyte ganglioside fraction that mediates group A porcine rotavirus recognition. $J$ Virol 1994; 68: 258-268.

13. Superti F, Donelli G. Gangliosides as binding sites in SA-11 rotavirus infection of LLC-MK2 cells. J Gen Virol 1991; 72: 2467-2474.

14. Willoughby RE, Yolken RH, Schnaar RL. Rotaviruses specifically bind to the neutral glycosphingolipid asialo-GM1. J Virol 1990; 64: 4830-4835.

15. Kunz C, Rudloff S. Biological functions of oligosaccharides in human milk. Acta Paediatr 1993; 82: 903-912.

16. Welsh JK, Skurrie IJ, May JT. Use of Semliki Forest virus to identify lipid-mediated antiviral activity and anti-alphavirus immunoglobulin A in human milk. Infect Immun 1978; 19: $395-401$.

17. Welsh JM, Arsenakis M, May JT. Effect on Semliki Forest virus and Coxsackie B4 of lipids common to human milk. $J$ Food Safety 1981; 3: 99-107.

18. Isaacs CE, Litov RE, Thormar H. Antimicrobial activity of lipids added to human milk, infant formula, and bovine milk. $J$ Nutr Biochem 1995; 6: 362-366.

19. May JT. Microbial contaminants and antimicrobial properties of human milk. Microbiol Sci 1988; 5: 42-46. 